\title{
Relationship Marketing Perspective on Salespersons' Transformational Leadership Behavior Effect
}

\author{
Nalin Abeysekera \\ Open University of Sri Lanka \\ E-Mail: nalinabeysekera@gmail.com \\ J. A. S. K. Jayakody \\ University of Colombo \\ E-Mail: susantha20002001@yahoo.com
}

\begin{abstract}
The study examined the impact of transformational leadership behavior of salespersons on their customers' relationship marketing behavior in the corporate banking sector in Sri Lanka. Researchers found that there is a relationship between transformational leadership and relationship marketing. The results of this study revealed that relationship marketing is well practiced by private banks than in state banks. Another important piece of information is that the majority of corporate customers who deals with the banks are males. The present study contributes to the practice of relationship marketing by shedding light on how salespersons can create and develop the practice of relationship marketing. Furthermore this research has identified what sort of relationship would create better communication and relationship with customers. Thus findings of this research will helpful to prepare training manuals, training guidance as well as training programs. Further these findings, especially transformational leadership qualities of salesperson can be used as one of the criteria's in selection process.
\end{abstract}

Keywords: Relationship Marketing, Transformational Leadership, Corporate Banking in Sri Lanka, Salesperson, Corporate Customers

\section{BACKGROUND AND OBJECTIVES}

According to the annual report of Central bank of Sri Lanka for 2006 financial service activities grew by $9.7 \%$, as against $6.5 \%$ growth in the previous year. Share of 
GDP of this sector is increasing, in 2005 the share of GDP was 9.5\% in financial services and in 2006 it further increased to $9.7 \%$. Activities of financial institutions further expanded during 2006. The total assets of the financial institutions increased by $18 \%$, reaching Rupees. 3,706 billion. This is 1.3 times the GDP. Commercial banks which accounted $57.4 \%$ of the total assets in the financial sector continued to hold a dominant position in the financial sector. Despite this significant contribution to GDP, and the increased competition due to the deregulation of financial sector, there is no evidence of major studies undertaken to examine the marketing practices such as relationship marketing or relationship banking in corporate banking sector in Sri Lanka. This is certainly disturbing as; literature suggested banking customers still prefer personal relationships as the principal means of communication and exchange between bank and client firm (Tyler and Stanley, 1999).

Bass (1997) shed light on how salespersons can adapt transformational leadership. Bass (1985) defined a transformational leader as one who motivates followers to do more than they originally expected to do. As literature suggests transformational leadership consists of four factors - charismatic leadership or idealized influence, inspirational leadership or motivation, intellectual stimulation, and individualized consideration. Accordingly transformational leadership can be employed to enhance the practice of personal selling. He did not attempt to ground his discussion on an appropriate theoretical base in marketing. But Jayakody and Sanjeewani (2006) addresses this gap, linking transformational leadership and relationship marketing at the level of the individual salesperson and his/her individual customer. However that study focused on only two dimensions of transformational leadership as the independent variables (dimensions of the idealized influence behavior and individualized considerate behavior).

\section{THE OBJECTIVE OF THE STUDY}

Having considered the possible positive impact of transformational leadership behavior of sales persons towards the customers (being transformational sales oriented) and finally the important role that sale representative can play in corporate banking, the following research problem is advanced in the study.

Is there any impact of transformational leadership behavior of salespersons of Sri Lankan corporate banking sector on their customers' relationship marketing behavior?

Hence present study examines whether the transformational leadership behavior of individual salespersons influence customers' trust in salespersons and their relationship commitment with the salespersons in the Sri Lankan corporate banking sector. 


\section{THEORETICAL BACKGROUND}

\section{Relationship Marketing}

In the increasingly competitive global financial world, relationship marketing has been advocated as an excellent way for banks to establish a unique long-term relationship with their customers. Most of the core products in commercial banking are fairly generic, and it is difficult for most banks to compete purely on this core service. Thus, recognition of the importance of relationship marketing has grown in recent years. Morris et al. (1998) explained that although relationship marketing is widely used, actual practice diverges across companies, from the concepts discussed in the literature. According to them, companies that claim to use relationship marketing do not always show the degree of commitment that the literature might suggest. Sheedy (1997) indicates that in banking, relationship marketing has certainly not always been implemented very carefully. This would suggest that there is still a need to better understand relationship marketing. Furthermore, there is little agreement on exactly what constitutes relationship marketing (e.g. Tyler and Stanley, 1999). These authors specifically call for more extensive research aimed at understanding relationships, and also note that the specifics of relationships would be context driven. Employees play a major role in shaping the service experience as the interface between the service and its provider is inseparable. Therefore, the service setting is especially conducive to customers forming relationships in services.

Both trust and commitment are invariably associated with the prerequisite that the relationship is of significantly high importance to one or both parties (Morgan and Hunt, 1994). Morgan and Hunt (1994) identified trust as a key construct in their model of relationship marketing. For the operationalization purpose definition of Morgan and Hunt was taken because it has considered the exchange and confidence which would be important in relationship marketing as a base. Since empirical studies (Morgan and Hunt, 1994; Tellefsen and Thomas, 2005; Jung and Avolio, 2000; Mukherjee and Nath, 2003 ) identify trust as an antecedent of commitment.

\section{Relationship Marketing in Corporate Banking Sector}

When taking into consideration of the banking sector, Perrien et al. (1992) suggested that strong competitive pressure has forced financial institutions to revise their marketing strategies and to stress long-lasting relationship with customers. Most banks have tried to differentiate from other banks by offering supporting services, which is a first step towards relationship marketing. Many banks would also claim to have implemented relationship marketing more fully by developing closer and closer 
relations with their clients. Whereas recent research has shown that corporate banking customers still prefer personal relationships as the principal means of communication and exchange between bank and client firm (Tyler and Stanley, 2001). Corporate banking can be defined as a broad term given to the different banking services that large companies, governments, or other big institutions need in order to function from day to day. According to the Weitz and Bradford, (1999) salespeople play a key role in the formation of long-term buyer-seller relationships. Furthermore the role of the salesperson can be considered as prime force behind customer loyalty as well (Colwell et all, 2009). And salespersons customer orientation cannot be ignored. Jaramillo and Grisaffe (2009) suggest that a customer-centric point of view helps salesperson to better recognize cues from customers and prospects .In this study customer relationship officer (CRO) has been considered as the focal point and in corporate banking sector the position of salesperson can be considered similar to CRO.

\section{Transformational Leadership}

According to Burns (1978), transformational leadership "occurs when one or more persons engage with others in such a way that leaders and followers raise one another to higher levels of motivation and morality", and results in a transforming effect on both leaders and followers. Transformational leadership raises the level of human conduct of both leader and follower. Transformational leaders throw themselves into a dynamic relationship with followers who will feel elevated by it and become more active themselves (Krishnan, 2001). Bass (1985) built on Burns (1978) work and described transformational leadership in terms of the impact that it has on followers; followers trust, admiration, and loyalty towards the leader.

A primary measure of transformational leadership has been Multi-factor Leadership Questionnaire (MLQ), developed by Bass and Avolio (1990). The MLQ is comprised of four distinct transformational leadership factors of idealized influence or charisma, inspirational motivation, intellectual stimulation, and individualized consideration. Accordingly to operationalized the transformational leadership concept Multi-factor Leadership Questionnaire (MLQ) was used with some modifications.

\section{Similarities in Relationship Marketing and Transformational Leadership}

Similarities of the concepts of transformational leadership and relationship marketing can be explained by using the concept of social exchange. According to Homans (1958), the initiator of the theory, it was developed to understand the social behavior of humans in economic undertakings. Responding to various market 
characteristics; while social exchange theory views the exchange relationship between specific actors as "actions contingent on rewarding reactions from others." (Blau, 1964).

Once it talks about the leader member exchange theory (describes how leaders in groups maintain their position through a series of tacit exchange agreements with their members) it comes from social exchange theory. In defining transformational leadership it says that a transforming effect on both leaders and followers. (Burns1978). According to Bass (1985) Transformational leaders develop relationships with their followers that go beyond pure economic and social exchange. Interestingly, marketing has been defined in terms of exchanges as well (Kotler and Armstrong, 1987) and examining individual-firm relationships in terms of rewards and costs helps to explain why consumers enter into such relationships. According to the Berry (2000) relationship marketing relies primarily on social bonds, which involves regular communication with customers and service continuity through a personal service representative.

Major outcomes of transformational leadership- trust and commitment- (Jung and Avolio, 2000) are the key variables of relationship marketing (Morgan and Hunt, 1994; Pillai and Sharma, 2003). Relationship marketing has emerged after the concept of transactional marketing and on the other hand transformational leadership emerged after the concept of transactional leadership. Thus from this also the relationship between two concepts can be understood. According to Bass (1997) both salespersons and leaders attempt to change and influence the perceptions, cognitions, decisions and behaviors of customers as well as their followers. This persuades researches to understand this relationship of transformational leadership and transformational selling in new inventive way.

\section{HYPOTHESES}

\section{Relationship between Customer Trust and Customer Relationship Commitment}

Trust and commitment are paired in the relationship marketing literature with very few researchers discussing one without the other. Both trust and commitment are invariably associated with the prerequisite that the relationship is of significantly high importance to one or both parties. (Morgan and Hunt, 1994).Since empirical studies (Morgan and Hunt, 1994; Tellefsen and Thomas, 2005; Jung and Avolio, 2000; Mukherjee and Nath, 2003) identify trust as an antecedent of commitment. In other words previous researches have positioned trust as a major determinant of relationship commitment. 
Therefore, it is hypothesized that:

H1: The higher the customer trust to the salesperson, the higher will be the customer relationship commitment with that salesperson.

Conger et al.,(2000) found that idealized influence affects trust generally defined with respect to follower reactions to the leader as well as leaders' behavior. These results are also supported by Jayakody and Sanjeewani (2006) who argued that idealized influence behavior of Salespersons positively influences customer trust. Thus, the following hypothesis is advanced.

H2: The higher the idealized influence behavior of the salesperson, the higher will be the customer trust in that salesperson.

Pillai et al., (1999) and Rowden (2000) supported the possible impact of inspirational motivation behavior on organizational commitment. From that following hypothesis is advanced.

H3: The higher the inspirational motivation behavior of the salesperson, the higher will be the customer commitment with that salesperson

Furthermore Pillai et al., (1999) and Rowden (2000) supported the possible impact of individualized considerate behavior on organizational commitment. Further Jayakody and Sanjeewani (2006) suggested that individualized considerate behavior of salespersons positively influences customer commitment. Therefore, it is hypothesized that:

H4: The higher the individualized considerate behavior of the salesperson, the higher will be the customer relationship commitment with that salesperson.

Meanwhile Pillai et al. (1999), Conger et al., (2000) suggested a possible impact of intellectual stimulation behaviors of leaders, on follower trust in the leader. From that following hypothesis is advanced

H5: The higher the intellectual stimulation behavior of the salesperson, the higher will be the customer trust in that salesperson.

The following conceptual framework has been developed for the purpose of this study 


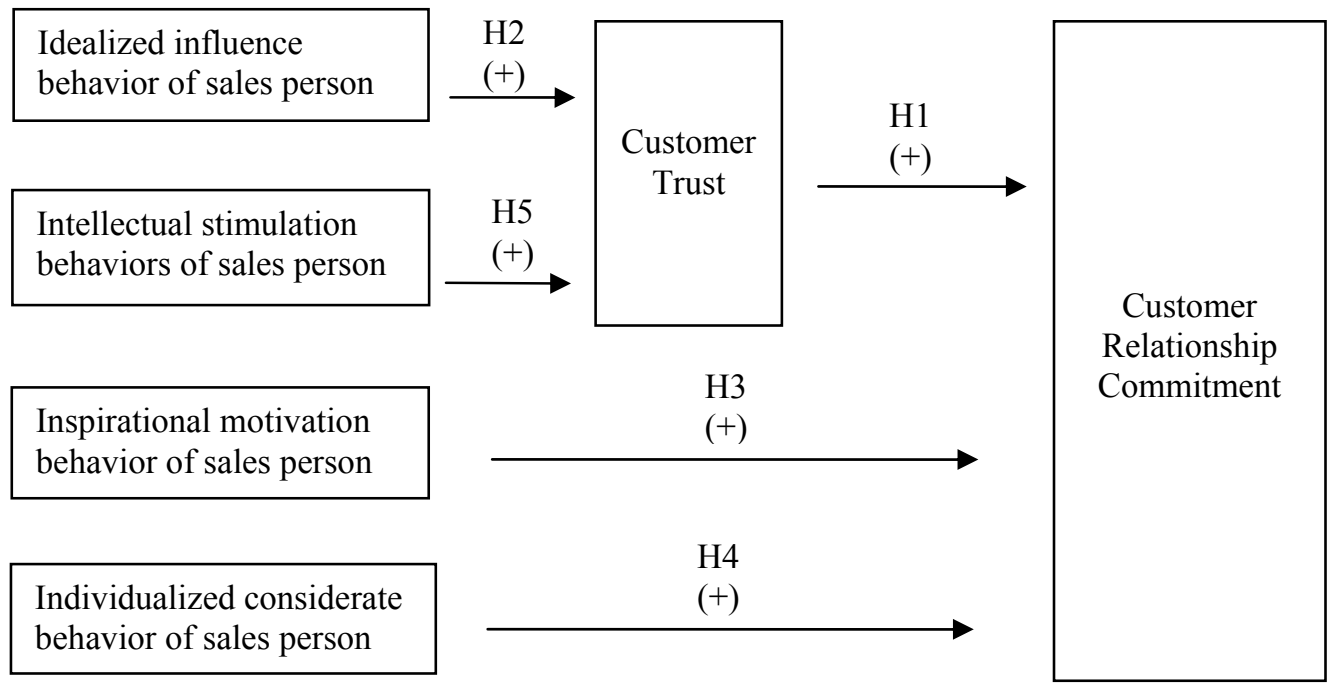

Figure 1 Impact of transformational leadership behavior of salespersons on customer trust and relationship commitment

\section{METHODOLOGY}

\section{Sample and Data Collection}

Data for this study was drawn from the questionnaire. Questionnaire consists of three parts. Part one was covered the two dimensions of relationship marketing; relationship commitment and customer trust. Part two covered the four dimensions of transformational leadership namely idealized influence, individualized consideration, intellectual simulation and inspirational motivation. Part three comprised of the background information about the respondents.

Before distributing the final questionnaire researcher did a pilot survey with ten (10) corporate customers five (5) each from two (2) state banks and private banks. After the pilot survey certain modifications were carried out according to the findings. Pilot survey was conducted to check whether the questionnaire was understandable or needs improvements etc.

According to the industrial experts around 700 CROs (Customer relationship officers) work in corporate banking departments of 23 commercial banks operating in Sri Lanka. It was decided to restrict the study to local banks due to dominant nature in Sri Lankan context (Central Bank, 2006). Thus two state banks and six private banks were selected. It was decided to select both state banks because the largest proportion of CROs (will be called salespersons hereafter) are attached to these two 
banks. Six major private banks were selected to make the sample representative and also because of the growing competition in the sector. According to the Economic and Social Statistics of Sri Lanka (2007) out of 1,345 branches of commercial banks operated, 592 branches operated in Western province (44\%). And out of 1,345 branches 774 represented by two state banks (57\%).

From these eight banks a random sample of 170 corporate customers were selected. Customers' names and contacts were obtained from the salespersons of that specific banks and researcher personally administer the survey henceforth. A total of 100 customers returned the questionnaire and all were suitable for the analysis. 52\% respondents were from state banks while $48 \%$ from the private banks. Hence it can be clearly seen that sample was evenly distributed among state and private banks.

The analysis was performed by SPSS 13.0. Linear regression technique has been used to test relationship between variables and test the hypothesis.

\section{ANALYSIS AND FINDINGS}

\section{Reliability Analysis}

In this study reliability was examined on all items. As a test of reliability Cronbach's Alpha was adopted to represent internal consistency. Table 1, shows the reliability test with all values grater than threshold of 0.60 (Walsh, 1995). Hence it can be conclude that the items reliably measure the defined constructs and variables.

Table 1 Results of Reliability Test

\begin{tabular}{lcc}
\hline \multicolumn{1}{c}{ Variables } & No. of items & Alpha \\
\hline Relationship Commitment & 5 & 0.891 \\
\hline Trust in Salesperson & 5 & 0.872 \\
\hline Idealized Influence Behavior & 10 & 0.838 \\
\hline Intellectual Stimulation Behavior & 10 & 0.840 \\
\hline Inspirational Motivation Behavior & 10 & 0.942 \\
\hline Individualized Considerate Behavior & 9 & 0.940 \\
\hline
\end{tabular}

Note. Survey data

\section{Correlation Analysis}

With the purpose of exploring the possible association between independent and dependent variables, the correlation matrix has been formed. The reported correlation coefficients are presented in table 2 . 
Table 2 Pearson Correlation of variables

\begin{tabular}{ccccccc}
\hline & IIS & IMS & ICS & ISC & CT & CRC \\
\hline IIS & & $0.891^{* *}$ & $0.889^{* *}$ & $0.836^{* *}$ & $0.847^{* *}$ & $0.821^{* *}$ \\
\hline IMS & $0.891^{* *}$ & & $0.865^{* *}$ & $0.875^{* *}$ & $0.790^{* *}$ & $0.724^{* *}$ \\
\hline ICS & $0.889^{* *}$ & $0.865^{* *}$ & & $0.873^{* *}$ & $0.784^{* *}$ & $0.747^{* *}$ \\
\hline ISC & $0.836^{* *}$ & $0875^{* *}$ & $0.873^{* *}$ & & $0.769^{*}$ & $0.756^{* *}$ \\
\hline $\mathrm{CT}$ & $0.847^{* *}$ & $0.790^{* *}$ & $0.784^{* *}$ & $0.769^{* *}$ & & $0.860^{* *}$ \\
\hline $\mathrm{CRC}$ & $0.821^{* *}$ & $0.724^{* *}$ & $0.747^{* *}$ & $0.756^{* *}$ & $0.860^{* *}$ & \\
\hline
\end{tabular}

$* *$ Correlation is significant at the 0.01 level (2-tailed)

Note. Survey data

According to that it is clear that there is a strong positive relationship between variables.

\section{Testing Hypotheses by using Regression Analysis}

A regression analysis is performed to test hypotheses. Table 3 presents, the result of the regression analysis of the hypotheses.

Table 3 Outcome of the Regression Analysis

\begin{tabular}{llccc}
\hline Hypotheses & \multicolumn{1}{c}{ Variable } & Coefficient $\beta$ & $\mathrm{T}$ & $\begin{array}{c}\text { Adjusted R } \\
\text { square }\end{array}$ \\
\hline Hypothesis 1 & $\begin{array}{l}\text { Customer Trust } \\
\text { Dependent-Commitment }\end{array}$ & 0.86 & 16 & 0.730 \\
\hline Hypothesis 2 & $\begin{array}{l}\text { Idealized Influence } \\
\text { Dependent-Trust }\end{array}$ & 0.85 & 15 & 0.710 \\
\hline Hypothesis 3 & $\begin{array}{l}\text { Inspirational Motivation } \\
\text { Dependent-Relationship } \\
\text { Commitment }\end{array}$ & 0.72 & 10 & 0.522 \\
\hline Hypothesis 4 & $\begin{array}{l}\text { Individualized Considerate } \\
\text { Behavior } \\
\text { Dependent-Relationship } \\
\text { Commitment }\end{array}$ & 0.75 & 11 & 0.563 \\
\hline Intellectual Stimulation & $\begin{array}{l}\text { Behavior } \\
\text { Dependent-Trust }\end{array}$ & 0.77 & 12 & 0.537 \\
\hline
\end{tabular}

${ }^{*} \mathrm{p}<0.01$ Two-tailed test

Note. Survey data 
It is hypothesized that, "The higher the customer trust in the salesperson, the higher will be the customer relationship commitment with that salesperson". As depicts in table 3 the adjusted $\mathrm{R}$ square is 0.730 , means strong positive relationship between relationship commitment with the salesperson and the customer trust.

Second hypothesis was, "The higher the idealized influence behavior of the salesperson, the higher will be the customers trust in that salesperson". The regression coefficient is 0.847 which is significant at $1 \%$ level of significance. This provides a clear support for hypothesis one that the higher the idealized influence behavior of the salesperson, the higher will be the customer trust in that salesperson. Further the result of the regression analysis shows that the adjusted $\mathrm{R}$ square is 0.710 reasonably higher for the regression indicating a strong relationship between idealized influence behavior of the salesperson and customer trust.

It is hypothesized that "The higher the inspirational motivation behavior of the salesperson, the higher will be the customer relationship commitment with that salesperson". As depicts in table 3, the regression coefficient is 0.724 and is statistically significant at $1 \%$ level of significance. Hence it can be admitted that the relationship commitment and inspirational motivation behavior of the salesperson is significant. Further the result of the regression analysis depicts that the adjusted $\mathrm{R}$ square is 0.522 , for the regression, indicating a relationship between inspirational motivation behavior of the salesperson and the customer relationship commitment with that salesperson.

Fourth Hypothesis was, "The higher the individualized considerate behavior of the salesperson, the higher will be the customer relationship commitment with that salesperson". The adjusted R square is 0.563 , indicating a strong relationship between individualized considerate behavior of the salesperson and customer relationship commitment. Coefficient Beta for the individualized considerate behavior is 0.747 , which is significant at $1 \%$ level of significance. Hence there is a strong positive relationship between individualized considerate behavior of the salesperson and the customer relationship commitment with that salesperson.

It is hypothesized that, "The higher the intellectual stimulation behavior of the salesperson, the higher will be the customer trust in that salesperson". The adjusted R square is 0.537 means reasonably high for the regression indicating the strong relationship between intellectual stimulation behavior of the salesperson and the customer trust. Coefficient Beta is 0.769 which is significance, meaning that the higher the intellectual stimulation behavior of the salesperson, the higher will be the customer trust in that salesperson by accepting hypothesis. 


\section{FURTHER DISCUSSIONS}

One of the important findings which are not linked to hypotheses formulated is the finding of the significant relationship between relationship marketing and the ownership of bank. It has revealed that relationship marketing is well practiced by private banks than in state banks. This is an important finding because of the competition in the industry and the dominant nature of the state banks in Sri Lanka.

Another important piece of information is that the majority of corporate customers who deals with the banks are males and most of the female like to visit their corporate bank only once a month. This will shed light for future research as to find out any possible impact of gender involvement in corporate banking in Sri Lanka.

\section{THEORETICAL IMPLICATIONS AND FURTHER RESEARCH}

The findings emanating from this study have a number of implications for both theory and practice. The present study advances Bass's conceptual work (Bass,1997) and findings of Jayakody and Sanjeewani (2006) which supported the relationship between transformational components and relationship marketing components with the evidence of literature. Bass (1997) shed light on how salespersons can adapt transformational leadership. According to him transformational and transactional leadership can be employed to enhance the practice of personal selling. But he did not attempt to ground his discussion on an appropriate theoretical base in marketing. But Jayakody and Sanjeewani (2006) addresses this gap, linking transformational leadership and relationship marketing at the level of the individual salesperson and his/her individual customer. They established a concrete link between transformational leadership and relationship marketing. However that study focused on only two dimensions of transformational leadership as the independent variables (dimensions of the idealized influence behavior and individualized considerate behavior). Since the present study focuses all the four variables in transformational leadership.

This study is limited to corporate banking in local commercial banks in Sri Lanka. It avoid the issue of generalizability future researchers should employ this study in many other fields of marketing including other sectors in banking (retail banking, foreign commercial banks etc), insurance industry as well as other services to empirically validate the findings of the study. Moreover this study only focused on how to relate transformational leadership in relationship marketing by using the customers' viewpoint. But it is better to identify the leadership qualities of sales persons. So, future researchers can focus on transformational leadership behavior of salespersons from the aspect of sales persons. 
Knowledge on relationship marketing can be broadened and deepened if it can use the full-range of leadership (Bass, 1997). It means by bringing together both transformational and transactional leadership, knowledge of relationship marketing can be expanded. This possibility is supported by the fact that, in practice, transaction marketing and relationship marketing activities may actually be used side by side in an effort to achieve different objectives. (Walsh et al, 2004). Hence both transactional and relationship marketing can be used together in future research.

\section{MANAGERIAL IMPLICATIONS}

The validity of bank-corporate client partnership strategy depends on how effectively it is implemented. For that training of salesperson is a must .For that it can use the four dimensions of transformational leadership to train salesperson. Firm can develop salesperson with the qualities of transformational leadership. It can be used as one of the core competency factor of the firm. Thus findings of this research will be helpful to prepare training manuals, training guidance as well as training programs

\section{Limitations of Research}

This research only focuses on the corporate banking sector in commercial banks in Colombo. Because of this, possibility of drawing generalization from the findings of the present study is limited. Further this study only focuses on the corporate banking sector in commercial banks. However, this can be further expanded into fields such as insurance and leasing.

This Research only focused on how to relate transformational leadership in relationship marketing by using the viewpoint of the customers. But it is better to identify the leadership qualities of sales persons. Thus, future researchers can focus on transformational leadership behavior of salespersons from the aspect of sales person.

\section{REFERENCES}

Bass, B. M. (1985). Leadership and Performance beyond Expectations. New York, NY: Free Press.

Bass, B. M. (1997). Personal selling and transactional/transformational leadership. The Journal of Personal Selling and Sales Management, 17(3), 19-28.

Bass, B. M., Avolio, B. J. (1990). Transformational Leadership Development: Manual for the Multifactor Leadership Questionnaire. Palo Alto, CA: Consulting Psychologists Press. 
Berry, L. L. (2000) Relationship Marketing of Services: Growing interest, Emerging Perspectives. In Sheth, J. N., Parvatiyar, A. (Eds.), Handbook of Relationship Marketing (pp. 149-170). London: Sage Publications.

Blau, P. (1964). Exchange and Power in Social Life. New York: Wiley.

Burns, J. M. (1978). Leadership. New York, NY: Harper \& Row.

Central Bank of Sri Lanka (2006). Annual Report, Colombo: Central Bank of Sri Lanka.

Conger, J. A., Kanungo, R. N. and Menon, S. T. (2000). Charismatic leadership and follower effect. Journal of Organizational Behavior, 21(2), 747-767.

Colwell, S. R., Hogarth-Scott, S., Jiang, D., Joshi, A. W. (2009). Effects of organizational and serviceperson orientation on customer loyalty. Management Decision, 47(10), 1489-1513.

Economic and social statistics of Sri Lanka (2007). Economic Indicators, Colombo: Central Bank of Sri Lanka.

Homans, G. C. (1958). Social Behavior as Exchange. American Journal of Sociology, 63(6), 597-606.

Jaramillo, Fernando., and Grisaffe Douglas B. (2009). Does Customer Orientation Impact Objective Sales Performance? Insights From A Longitudinal Model In Direct Selling. Journal of Personal Selling \& Sales Management, 29(2), $167-178$.

Jayakody, J. A. S. K., Sanjeewani, W. M. A. (2006). The impact of transformational leadership behavior of salespersons on their customer relationship marketing behavior. International Journal of Bank Marketing, 22(7), 461-447.

Jung, D. I., Avolio, B. J. (2000). Opening the black box: an experimental investigation of the mediating effects of trust and value congruence on transformational and transactional leadership. Journal of Organizational Behaviour, 21(8), 949-964.

Kotler, P., Armstrong, G. (1987). Marketing: An Introduction. Englewood Cliffs, NJ: Prentice-Hall.

Krishnan, V.R. (2001). Value systems of transformational leaders. Leadership \& Organization Development Journal, 22(3), 126-132.

Morgan, R. M., Hunt, S. D. (1994). The commitment-trust theory of relationship marketing. Journal of Marketing, 58(3), 1-38.

Morris, M. H, Brunyee, J, Page, M (1998). Relationship marketing in practice: myths and realities. Industrial Marketing Management, 27(4), 359-371.

Mukherjee, A. and Nath, P. (2003). A model in trust in online banking. International Journal of Bank Marketing, 21(1), 5-15. 
Perrien, J, Filiatrault, P, Ricard, L (1992). Relational marketing and commercial banking: a critical analysis. International Journal of Bank Marketing, 10(7), 25-29.

Pillai, R., Schriesheim, C. A. and Williams, E. S. (1999). Fairness perceptions and trust as mediators for transformational and transactional Leadership: a two-sample study. Journal of Management, 25(6), 897-933.

Pillai, K. G., Sharma, A. (2003). Mature relationships: why does relational orientation turn into transaction orientation? Industrial Marketing Management, 32(1), 643-651.

Rowden, R. W. (2000). The relationship between charismatic leadership behavior and organizational commitment. The leadership and Organization Development Journal, 21(1), 30-35.

Sheedy, E (1997). Marketing derivatives: a question of trust. International Journal of Bank Marketing, 15(1), 22-31.

Tellefsen, T. and Thomas, G. P. (2005). The antecedents and consequences of organizational and personal commitment in business service relationships. Industrial Marketing Management, 34(1), 23-37.

Tyler, K, and Stanley, E. (1999). Marketing financial services to businesses: a critical review and research agenda. International Journal of Bank Marketing, 17(3), 98-115.

Tyler, K., and Stanley, E. (2001). Corporate banking: the strategic impact of boundary spanner effectiveness. International Journal of Bank Marketing, 19(6), 246-260.

Walsh, S., Gilmore, A., Carson, D. (2004). Managing and implementing simultaneous transaction and relationship marketing. International Journal of Bank Marketing, 22(7), 468-483.

Walsh, W. B. (1995). Tests and Assessment ( $3^{\text {rd }}$ edition). New Jursey: Prentice Hall.

Weitz, B. A, Bradford, K. D (1999). Personal selling and sales management: a relationship marketing perspective. Journal of the Academy of Marketing Science, 27(2), 241-254. 